\title{
Financial Literacy Key to Retirement Planning in Malaysia
}

\author{
Folk Jee Yoong (Corresponding author) \\ Institute of Post Graduate Studies, University of Malaya \\ 4, Lorong 14/37E, 46100 Petaling Jaya, Selangor, Malaysia \\ E-mail: yoong61@gmail.com
}

Beh Loo See

Faculty of Economics \& Administration, University of Malaya, Kuala Lumpur, Malaysia

E-mail: lucybeh@um.edu.my

Diana-Lea Baronovich

Faculty of Education, University of Malaya, Kuala Lumpur, Malaysia

E-mail: diana@um.edu.my

Received: January 5, 2012 Accepted: January 18, 2012 Published: March 1, 2012

doi:10.5539/jms.v2n1p75 URL: http://dx.doi.org/10.5539/jms.v2n1p75

\begin{abstract}
This paper examined the influence of financial learning on retirees' retirement financial planning preparation. 750 questionnaires were distributed with a $53.9 \%$ return rate. Three hypotheses were analysed using hierarchical regression analysis. The results revealed that some mediating effect existed between financial learning and behavioural assessment of personal finance, and that the older age groups had mediating effect on the relationship between financial learning and subjective perception of satisfaction with personal finance. Within this context, respondents were satisfied with their financial situation from the behavioural assessment of personal finances, subjective perception and perceived financial well-being perspective. The study also indicated that some mediating effect existed between financial learning and behavioural assessment of personal finance, and that the older age groups (above 50 years) had mediating effect on the relationship between financial learning and subjective perception of satisfaction with personal finance.
\end{abstract}

Keywords: Economic well-being, Financial planning, Financial education, Literacy

\section{Introduction}

The ageing phenomenon has turned Malaysia into an ageing society currently with $6.3 \%$ of its population being elderly people (over 60 years old) in 2000 and estimated at $7.4 \%$ in 2010 and $9.9 \%$ in 2020 (Taha and Mat, 2003). This phenomenon has posed serious problems to policy makers and people nearing retirement with little savings, apart from becoming a heavy financial burden for their dependent children especially in the low echelon of society. The problems are identified as (a) the low public-sector employees' pension payments and the inadequate private-sector employees' EPF savings (Caraher, 2000; Kumar, 1997; Thillainathan, 2004); (b) the gap between rising Malaysian living costs and living standards; (c) generally speaking, Malaysians' life longevity, susceptibility to diseases, rising medication and healthcare costs, as well as unavailability (in certain areas) and medical services privatisation, and (d) finally the extended family systems' erosion and the nuclear family units' emergence (Chan, 1997).

On healthcare costs issue, Chia's (1996) study has indicated that elderly people aged 60 and above require greater medical attention by visiting medical and healthcare centers, six times a year, on an average. Thus, Malaysians' life expectancy improvement from 72.76 in 2007 to 73.29 in 2008 (Dept of Statistics, 2008) would further imply heavier financial burden with rising medication/healthcare costs. On the retirement resource issue in Malaysia, Kumar (1997) has also revealed that savings and retirement resources adequacy problems in the low- and mid-income groups were serious, as $38.2 \%$ of the total employed 'informal sector' Malaysians in 1998 
were not covered by the EPF and any pension scheme i.e. the two pillars (Fox and Palmer, 2001). Of the remaining $61.8 \%$ covered employees, there are doubts that the EPF scheme, being subjected to lump-sum payments or pre-retirement withdrawals (Thillainathan, 2004), would be adequate to meet contributors' post-retirement financial needs (Caraher, 2000). Meanwhile, the pension payments scheme, unless it can be revised upward in line with inflations, would continue to present a similar problem to pensioners. These problems merit a reexamination or examination of the relevant financial learning issue, given the fact hat the learning theory emphasizes the significant interaction between the individual, the nature of the material to be learnt and the context, within which learning takes place (Hershey and Mowen, 2000). For all age cohorts, their financial resources influence spending over their life cycle (Tan and Folk, 2011).

The study examines the Malaysians' financial issues from the perspectives of their financial planning and expectations especially the subjective perception, behavioral assessment objective, and overall financial wealth. It also examines whether they are able to achieve a better retirement through improving their different educational levels, and value systems. The outcome reveals (a) Malaysians' financial wellness level in order to provide useful information to financial counselors or financial planners, (b) Malaysians managing their own finances and investments; and (c) the level of their retirement preparedness as reflected by the importance of financial education (Bayar et al., 1996; Hogarth et al., 2003; Joo and Grable, 2005; Kim et al., 2005).

\section{Literature review}

In early studies, the 'lifecycle' hypothesis by Ando and Modigliani (1963) dealt with economic decisions on retirement savings in particular the rationalization of an individual's income in order to maximize its utility over his lifetime, whereas the 'permanent income' hypothesis by Friedman (1957) investigated pre-and post-retirement living standards in "straightening out the consumption stream". In recent studies, correlations are found in existence between education and financial literacy (Fletcher, Beebout and Mendenhall, 1997; Clark et al., 2003), while other studies have indicated that, by increasing an individual's literacy, he could improve his mental faculty in predicting consequences of his action (Becker and Mulligan, 1997; Barlett and Kotrlik, 1999; Bolhuis, 2003; Sebstad and Cohen, 2003; Loibl and Hira, 2005). In a sense, these studies have principally dealt with different effects impacting an individual's financial behavior (Fletcher, Beebout and Mendenhall, 1997; Kim, 2000), and personal savings and retirement investment (Joo and Grable, 2001). More recent studies have also found financial education as a form of financial knowledge being positively related to retirement planning (Ekerdt and Hackney, 2002, Lusardi, 1999, 2000), and personal savings and retirement investment (Joo and Grable, 2001). Financial education has been investigated inter alia as a tool for saving accumulations (Joo and Garman, 1998; Mannix, 1998; Fox and Palmer, 2001; Lusardi and Mitchell, 2005; Lyons et al., 2006), as financial matters constantly affect our daily lives (Staten et al., 2002; Jacobs-Lawson and Hershey, 2005; Lim, 2003). Studies by Mitchell and Moore (1998) have also found many people without retirement planning for lack of domain-specific knowledge. Most recently, other studies have also emerged indicating that the least literate are also the least likely to plan and save for retirement, while those who cannot do simple and compound interest calculations are also less likely to calculate their retirement needs (Lusardi and Mitchell, 2006, 2007, 2008). Besides, difficulties with interest calculations are also documented in some other studies (Lusardi and Mitchell, 2007; Lusardi and Tufano, 2008; van Rooij et al., 2007). Evidence has also shown that financially unsophisticated households tend to avoid the stock market (Kimball and Shumway, 2007; Van Rooij et al., 2007), and that they are less likely to choose mutual funds with lower fees (Hastings and Tejeda-Ashton, 2008). Furthermore, people unable to correctly calculate interest rates tend to borrow more and accumulate less wealth (Stango and Zinman, 2008). The above summarises some of the relevant studies on the implications of financial education.

The study looks at Malaysians with their embedded cultural and ethnic diversities on the assumption that they would generally acquire the requisite skills in career planning, and obtain appropriate financial education to plan for their retirement financial needs. However, it is an accepted fact that some Malaysians may sometimes maintain certain "couldn't care less attitude" towards life, and depend on parents' handouts in time of financial needs. In the light of the above, the study would be intended for those in need of retirement financial planning and for financial advisers or counselors in evaluating the niche market for financial planning in Malaysia.

Given Malaysia's highly competitive work environment, individuals' financial education and their expectations of future financial position are invariably inter-related. The study focuses on the importance of the inter-relationships between financial education, financial literacy and expectations of future financial savings. Whereas the most important old age income sources are the EPF savings and pension schemes notwithstanding their weaknesses, many of the EPF contributors and pensioners in this formal sector may still face the 
uncertainty of their retirement years because of possible income inadequacy (Caraher, 2000). A summary of the hypotheses, derived from the above discussions, are examined as follow:

Hypothesis 1: Controlling for demographic attributes, financial learning makes a significant contribution to the explained variance in financial literacy.

Hypothesis 2: Controlling for demographic attributes and financial learning, financial literacy will make a significant contribution to the explained variance of financial satisfaction.

Hypothesis 3: Financial literacy will mediate the relationship between financial learning and financial satisfaction.

\section{Conceptual framework}

The following conceptual framework has been specifically developed to depict the selected factors affecting the well-being of Malaysia's elderly people. Consequently, according to the conceptual framework, factors such as economic conditions, demographic characteristics and cultural dimensions are expected to have a direct impact on the people especially the elderly closely associated with the healthcare infrastructure and demographic trends. Furthermore, demographic trends e.g. age, gender, marital status, housing tenure, income, lifestyle status, number of young children and occupation are inter-related to personal financial wellness, stability and resource adequacy.

Insert figure 1 here

\section{Methodology}

The study employs the quantitative method to obtain the relevant primary data. Sampling was drawn from individuals residing in the Klang Valley, where there was a projected metropolitan population of 6.8 million in 2008 as against the 5.1 million in 2004 (Dept of Statistics, 2008). 750 questionnaires were randomly distributed by research assistants to adults over 20 years old in the Klang Valley (the largest population centre in Malaysia) yielding a $53.9 \%$ useable return rate. Non-probability sampling was used to use to target the three major ethnic groups i.e. Malays, Chinese, and Indians. The questions comprise of Likert-like questions and mainly closed-ended. Alpha coefficient of above 0.6 is used.

Constructs was tested using indexes which are multi-item instruments to measure a single concept with several attributes. The Factor Analysis tests were used to identify significant components which were included in the final equation; it was for finding factors within a large distribution of scores. Items with primary factor loadings greater that 0.4 was judged sufficient. To identify the financial wealth from the samples, the correlation and multiple regression analysis was adopted to explore the personal financial wealth profile, based on respondents' demographic characteristics. Regression Analysis was used to measure the amount of variance explained in the dependent variable by the predictors. The common Statistical Package for Social Science or SPSS was used to analyse data collected. Multiple regression tests were carried out for all the hypotheses as there are several independent variables involved. Checks were carried out for mediating effect on some variables using hierarchical regression tests. Hierarchical regression was used to test the significance of each independent variable as reflected in the conceptual framework. Descriptive Analysis was first examined, followed by multiple regression analysis.

\subsection{Scale development}

The thrust of the research questions for this study was focused upon elderly people's well-being especially their retirement financial adequacy. The main issue was the dependent variable for personal well-being in formulating the necessary hypotheses. Various constructs were developed using Factor Analysis (FA) to identify underlying variables in order to explain the pattern of correlations within a set of observed variables. These constructs were used to identify a small number of factors to explain most of the variances observed in a much larger number of manifest variables. Through a complex procedure performed by special software, the FA examined each question within a group of questions to determine how they accumulate together. The independent variables are normal and continuous with, at least, 5 variables being loaded onto a factor, while the sample size comprised 50 observations with over 5 observations per variable. The principal component analysis was used to find the fewest number of variables to explain the most variances. Factors were extracted whenever eigenvalues were greater than 1.0 or where the Scree Test visually indicated how many factors could be extracted. Factor loadings were the correlations between the factor and the variable, where a loading of 0.4 or higher was typically required to attribute a specific variable to a factor. Finally, several scales were developed combining the various questions as mentioned below. Financial learning is set to represent the independent variables, and economic well-being represents the dependent variables (key variables for the study). 
Table 1 below summarises the result of the scale development.

\section{Insert table 1 here}

Financial Literacy Scale was developed from answers to a number of questions. Specifically, they had to rank five of the questions on a five-point scale ranging from 'Not at all' to 'Very Well' and the rest of the questions on a seven-point scale ranging from 'Strongly Disagree' to 'Strongly Agree'. For internal scale consistency, results of the seven-point scale were recoded onto a five-point scale and then checked using the Cronbach alpha coefficient. The Financial Literacy Scale (FLS) had a Cronbach Alpha of 0.894 indicating a high reliability. After applying the FA Test through the use of the rotated component matrix (KMO - 0.876), the study had resulted in two separate components

Economic Well-Being Scale comprised of 12 questionnaire items, including: a) 'The way you have used your money', b) 'Your ability to meet large unexpected expenses', c) 'The amount of your unpaid balances on your credit card', d) 'I worry about being able to pay monthly living expenses' and so forth. Responses thereto were required to measure subjective perception with income adequacy. The Cronbach Alpha depicted a 0.877 indicating a high reliability on the Economic Well-Bing Scale (EWBS). The FA Test using the rotated component matrix $(\mathrm{KMO}-0.834)$ had produced the four scales for testing the sub-hypotheses.

\section{Data analyses and findings}

The results of the descriptive analysis were tabulated in Table 2 below. This was followed by the multilevel regression analysis for Hypotheses 1 to 3 (Table 3).

\section{Insert table 2 here}

As a group, respondents had reported moderate income. By categorisation, $65.1 \%$ of them had personal incomes less than RM5,000; 8.9\% had personal income above RM10,000; 18.6\% had personal income between RM3,000 and RM3,999; and 18.1\% had personal income between RM2,000 and RM2,999, respectively. Homeownership has accounted for a large part of individuals' expenditure, which had a significant impact on retirement planning.

\subsection{Hypothesis testing}

Hypotheses 1, 2 and 3 were tested using the hierarchical regression analysis. For Hypotheses 1 and 2, the nine demographic variables were first entered into the regression equation as independent variables in order to predict the financial literacy before the input of financial learning variables. A comparison was then made between the model (with demographic variables) and the other model (with additional independent variables) with a view to determining whether there were significant differences between the two models. In testing Hypothesis 2, the first step was to enter the nine demographic variables along with the learning variables into the regression equation before the financial literacy variables were entered into the equation as independent variables in order to predict the economic well-being. Thereafter, comparisons were made between one model comprising demographic/learning variables with another model comprising additional independent variables to see whether there were any significant differences. Hypothesis 3 tested under the hierarchical regression analysis has suggested some mediation of the relationship between financial learning and economic well-being. Accordingly, further testing was performed using the criteria established by James and Brett (1984) to see whether the mediation effects existed under three conditions. For condition 1 to be met, the independent variable must be significantly correlated with the mediator variable. For Condition 2 to be met, the mediator variable must be significantly related to the dependent variable, while for Condition 3 to be met, the influence of the mediator variable was held constant, and the effect of the independent variable on the dependent variable should be non-significant (Allen, 2001). The significance of the regression coefficient associated with the step-two independent variable was also used to determine if mediation effects existed.

\section{Insert table 3 here}

\section{H1: Financial Learning and Financial Literacy}

Controlling for demographic attributes, financial learning makes a significant contribution to financial literacy level. Regression analysis was used to describe financial literacy according to demographic characteristics or variables, namely: age dummy variable (DAge), education, gender, home ownership, income (F1), marital status dummy variable (DMarr1), number of children, and employment type dummy variable (DEmp). The issue of financial literacy was examined according to respondents' financial learning with these learning variables comprising items QD1 (a to e) and QD2 (a to f). As mentioned earlier, the FA has enabled two financial literacy scales to be developed for testing the following sub-hypotheses. 
H1.1: $\boldsymbol{H}_{0}$ - Controlling for demographic attributes, financial learning makes a significant contribution to financial literacy explanation.

The hierarchical multiple regression results on financial literacy explanation ("LITEXPL") showed that the demographic characteristics had explained $18.0 \%$ of the variance of the dependent variables, while the $\mathrm{R}$ square suggested that there were other factors which had explained LITEXPL besides the nine demographic characteristics. Among them, employment type and income had significant coefficients, while income was also a relatively more significant LITEXPL predictor than employment type. The financial learning variables were significant at the 0.001 level $\left(\Delta \mathrm{R}^{2}=.139, \Delta \mathrm{F}=5.497, \mathrm{p}<.001\right)$ resulting in the null hypothesis being rejected.

H1.2: $\boldsymbol{H}_{\boldsymbol{0}}$ - Controlling for demographic attributes, financial learning makes a significant contribution to financial literacy knowledge.

The regression results on financial literacy knowledge ("LITKNOW") revealed that the nine demographic characteristics had explained $9.2 \%$ of the variance of the dependent variables, while the $\mathrm{R}$ square suggested that there were also other factors explaining LITKNOW. Among the demographic characteristics, education level and income had significant coefficients, while income was a relatively more significant predictor of the LITKNOW than education. The financial learning variables were significant at the 0.001 level $\left(\Delta \mathrm{R}^{2}=.151, \Delta \mathrm{F}=\right.$ $5.234, \mathrm{p}<.001)$. Accordingly, the null hypothesis was rejected.

\section{H2: Financial Literacy and Economic Well-being}

Controlling for demographic attributes and financial learning, financial literacy makes a significant contribution to economic well-being level. In dealing with respondents' economic well-being according to their financial literacy level, the following demographic variables are also examined: ethnicity, gender, age, marital status, number of children, home ownership, education level, income, and employment classification. The regression analysis has identified four main factors for economic well-being being used as dependent variables. These are discussed below under Hypotheses 2.1, 2.2, 2.3, and 2.4.

H2.1: $\boldsymbol{H}_{\boldsymbol{\theta}}$ - Controlling for demographic attributes and financial learning, financial literacy makes a significant contribution to Subjective Perception of Personal Finance (SUBPERC).

The regression analysis has revealed that among the nine demographic characteristics, the over 60 -year age group, income and home ownership had significant coefficients, where the Beta coefficients represented the relative contributions of the variables in the equation. The results further revealed that older age cohorts was a relatively more significant SUBPERC predictor than the other two demographic variables, while Model 1 comprising the demographic and learning variables was significant at the 0.001 level $\left(\Delta \mathrm{R}^{2}=.211, \Delta \mathrm{F}=3.637\right.$, $\mathrm{p}<.001)$. When literacy variables were added in Model 2 , the $\mathrm{R}$ square increased significantly $\left(\Delta \mathrm{R}^{2}=.021, \Delta \mathrm{F}=\right.$ 4.594, $\mathrm{p}<.05)$. The regression results had therefore fully supported the above statement in Hypothesis 2.1

H2.2: $\boldsymbol{H}_{\boldsymbol{0}}$ - Controlling for demographic attributes and financial learning, financial literacy makes a significant contribution to Behavioural Assessment of Personal Finance (BEHASS).

The regression tests showed that, of the eight demographic characteristics, education was the only significant variable in explaining the Behavioural Assessment of Personal Finance (BEHASS), as it was significant at the 0.05 level, when Model 1 comprising demographic and Learning variables was significant at the 0.05 level $\left(\Delta \mathrm{R}^{2}\right.$ $=.108, \Delta \mathrm{F}=1.644, \mathrm{p}<.05)$. In Model 2 , the regression tests have also shown that, when literacy variables were added, the $\mathrm{R}$ square increased significantly $\left(\Delta \mathrm{R}^{2}=.032, \Delta \mathrm{F}=6.313, \mathrm{p}<.01\right)$, indicating the support of the statement in Hypothesis 2.2.

H2.3: $\boldsymbol{H}_{\boldsymbol{0}}$ - Controlling for demographic attributes and financial learning, financial literacy makes a significant contribution to Satisfaction with Financial Situation (FINSAT).

The regression results of LITERACY, Learning, and demographic variables with FINSAT had indicated that the equation explained $19.9 \%$ of the FINSAT variance, and that, among the nine demographic characteristics, only the over 60 -year age group and ethnicity was significant at the 0.01 level. Model 1 comprising the demographic and learning variables was also significant at the 0.001 level $\left(\Delta \mathrm{R}^{2}=.199, \Delta \mathrm{F}=3.370, \mathrm{p}<.001\right)$. The results further revealed that, when Literacy Constructs (LITEXPL and LITKNOW) were added in Model 2, the R square increased significantly $\left(\Delta \mathrm{R}^{2}=.050, \Delta \mathrm{F}=10.318, \mathrm{p}<.001\right)$, indicating that Hypothesis 2.3 was also fully supported.

$\boldsymbol{H}$ 2.4: $\boldsymbol{H}_{\boldsymbol{\theta}}$ - Controlling for demographic attributes and financial learning, financial literacy makes a significant contribution to perceived financial well-being (PERWELL). 
While the tests revealed the following demographic variables (income, age and education level) as significant, the older age group was even a relatively more important PERWELL predictor. The equation with demographic variables explained $25.1 \%$ of the variance of Perceived Financial Well-Being (PERWELL), and the Literacy Construct (LITKNOW) was significant at the 0.01 level on its own merit. The tests have also indicated that Model 1 with demographic and learning variables was significant $\left(\Delta \mathrm{R}^{2}=.251, \Delta \mathrm{F}=4.557, \mathrm{p}<.001\right)$, and that, with the input of literacy variables in Model 2 , the $R$ square has increased significantly $\left(\Delta \mathrm{R}^{2}=.018, \Delta \mathrm{F}=4.128\right.$, $\mathrm{p}<.05$ ) indicating that Hypothesis 2.4 was fully supported.

\section{H3: Financial Learning and Financial Well-being}

Financial literacy mediates the relationship between financial learning and economic well-being. The questions were adapted from reputed studies (Loibl and Hira, 2005; Garman et al., 1999). The economic well-being comprises the following four components: Behavioural Assessment of Personal Finance (BEHASS), Perceived Financial Well-Being (PERWELL), Satisfaction with Financial Situation (FINSAT) and Subjective Perception of Personal Finance (SUBPERC) discussed under Hypotheses 3.1, 3.2, 3.3 and 3.4.

H3.1: $\boldsymbol{H}_{\boldsymbol{\theta}}$ - Financial literacy mediates the relationship between financial learning and behavioural assessment of personal finance (BEHASS).

For financial learning and demographic variables with Behavioural Assessment of Personal Finance (BEHASS), the regression results showed that the independent variables had explained $3.5 \%$ of the BEHASS variance, but only the education level (of all the demographic characteristics) was significant at the 0.05 level. The results have indicated that the regression coefficient associated with financial learning variable was fairly strong. However, it was not significant when being first entered in Step $2(b=0.171, p<0.01)$. When the financial literacy variable was entered in Step $3(b=0.139, p<.01)$, the regression coefficient associated with financial learning has even become less significant $(\mathrm{b}=0.139, \mathrm{p}<.01)$. This has indicated some mediating but insignificant effect thereby leading to the rejection of the null hypothesis.

H3.2: $\boldsymbol{H}_{\boldsymbol{0}}$ - Financial literacy mediates the relationship between financial learning and perceived financial well-being (PERWELL).

The regression tests found four of the demographic characteristics (the over 50-year age group, income, marriage and education level) as significant at the 0.05 level. The older age group was a relatively more important predictor of perceived financial well-being (PERWELL). While Step 1 of the tests had explained $19.1 \%$ of the PERWELL variance, the $\mathrm{R}$ square had however suggested the existence of other factors, which had explained the PERWELL variance. The tests have further found the regression coefficient associated with financial learning variable as very significant when being first entered in Step $2(b=-.163, p<0.05)$. When, however, the financial literacy variable was entered in Step 3, the regression coefficient associated with financial learning had become less significant $(b=-.134, p=.066$ ). Consequently, the null hypothesis was accepted.

H3.3: $\boldsymbol{H}_{0}$ - Financial literacy mediates the relationship between financial learning and satisfaction with financial situation (FINSAT).

For financial learning and demographic variables with FINSAT, the regression results showed that the first model explained $10.3 \%$ of the variance of satisfaction with personal financial situations, and that two demographic characteristics (over 60-year age group and ethnicity) were significant at the 0.01 level. The results have further indicated the regression coefficient associated with financial learning variable as significant when being first entered in Step $2(b=.168, p<0.01)$. When the financial literacy variable was entered in Step $3(b=$ $0.196, \mathrm{p}<.01)$, the regression coefficient associated with financial learning became not significant $(b=.141, p$ $<.01)$. This had intimated a not significant mediating effect thereby leading to the null hypothesis being rejected.

H3.4: $\boldsymbol{H}_{\boldsymbol{0}}$ - Financial literacy mediates the relationship between financial learning and subjective perception of personal finance (SUBPERC).

On this assumption, efforts were made to conduct the regression tests which showed that Model 1 had explained $14.5 \%$ of the variance of the dependent variables and that, among the nine demographic characteristics, those with significant coefficients were the over 60 years age group and income. Furthermore, older age cohort was a relatively more important predictor of subjective perception of personal finance (SUBPERC) than other demographic characteristics. The test results have indicated that the regression coefficient associated with financial learning variable was significant when being first entered in Model $2(b=-.155, p<0.01)$. However, the results changed, when the financial literacy variable was entered into Model $3(b=0.114, p=.059)$, and the regression coefficient associated with financial learning has become bigger and more significant $(b=.153, p$ 
$<.01)$. As it was not significant at the 0.05 level, no mediating effect was noted thereby leading to the null hypothesis being accepted.

\section{Concluding remarks}

The study reveals some demographic characteristics as significantly related with various personal financial well-being measures. For example, respondents' personal income explains a significant variance of the subjective perception scale, behavioural assessment scale, perceived financial well-being scale, satisfaction with financial situation scale, and the amount of their retirement funds and personal income. Furthermore, personal income positively affects personal financial well-being. Home ownership is also found positively related with the subjective perception index, perceived financial well-being, and satisfaction with financial situation, while more married than single respondents carry more credit card debts. The study also reveals age as positively related with retirement funds but negatively with credit card debts, whereas older respondents 50 years or above will have more reserve funds and less credit card indebtedness. While financial learning is significantly associated with better financial management practices and economic well-being, financial literacy has only moderating effect on relationships between financial learning and economic well-being. Despite the above findings, the changing demographics per se are expected to impact on the pattern and timing of people's investment strategies, and on their long-term retirement income adequacy, following longer life expectancies. Consequently, the longer the life expectancy the lower will be the average real income, given Malaysia's inflation rates. These serious problems will need to be properly addressed.

Additionally, the study also shows close relationships between respondents' financial preparedness (both calculated and perceived) and their age, education level, and investing habits. Hence, with increasing age, they will have a better understanding of their cost of living and retirement expense requirements, thereby enabling them to gauge at what stage of their lives they will achieve financial readiness for retirement. However, they must begin their investments with their retirement goals, as this provides them with a clearer picture of not only their investment potentials but also their goal achievement. The study also reveals that more educated Malaysians are financially more prepared for retirement as found in the findings of Lusardi and Mitchell (2006, 2007, 2008), and that to help the lesser educated requires communication methods, which do not rely heavily on numeracy, statistics and analytical reasoning. It calls for a need to organise information in such a way that the instructions can easily be followed.

Over and above, the study has examined four perspectives i.e. subjective perception, behavioral assessment, financial well-being, and perceived financial well-being. The enquiry into the subjective perception and behavioral assessment produce no noteworthy results. On perceived financial well-being, the findings indicate that financial education stimulates financial satisfaction, while meeting the challenge of keeping current on constantly changing financial knowledge. The examination of perceived financial well-being also lends support to the hypotheses that those planning to either partially retire or perceive themselves as prepared for retirement are more likely to have financially prepared for retirement. In their decision making process, those perceiving themselves as financially prepared might, however, be initially, uncertain of the stage of their preparedness leading them to seek professional assistance to ensure preparedness. Despite these findings, there is room for improvement on the educational relevance and content as revealed by the study. In this respect, financial counselors and financial planners should identify the niche market for providing the type of professional expertise required, for example, in areas of safe and high-yield investments with excellent track records. In view of the fast-changing uncertain economic environment, Malaysians should take absolute precautionary measures when assessing the critical situation before embarking on any investment portfolios. Additionally, the strategies must also include, inter alia, examining the target company's management expertise, dividend policy, track records, and industry-wide competitiveness. Additionally, self-directed life-long learning and part-time studies should become part of their learning curve for a number of reasons including cost and time constraints, career planning and self-actualization, and so forth. Needless to say, future 'financial' learners will have to become self-directed in absorbing the enormous amount of information in keeping with changing trends, and they are expected to implement new and effective methods to generate a higher return from investments so achieving their future goals and better retirement preparedness. Towards this end, there is an urgent need to look into the relationships between other variables such as side income, unit trust income, insurance planning, age of initial investment, and legal structure, as these are important contributing factors to effective financial planning for retirement. As briefly discussed earlier, some of the study's findings have detected any significant relationships, because of time constraint and other factors. A further investigation will certainly help bring about more common demographics of retirement. 
The study also shows that respondents generally perceived themselves as financially prepared for retirement. However, the relevant information given was inconclusive as their income sources for their semi- and full retirement were not adequately revealed or readily discernible from responses received. As such, a more in-depth investigation would be justifiable. In so doing, the primary retirement income sources could be clearly identified and designated as reliable to ensure that respondents in similar circumstances could be genuinely perceived as prepared for retirement at a specific time. As a further enquiry, it is also useful to look into the reasons or circumstances as to why some people were not seeking professional help for their retirement planning as clearly indicated as their responses.

Finally, a developmental approach to population ageing would ensure that all people are fully aware of their ageing process by taking an active role to integrate ageing issues and concerns. Younger people should also take responsibility to maintain a healthy lifestyle and understand the life-long process involved and start providing for their own old age security through various schemes, on the other. The latter should also become the catalyst in promoting policies and programs on ageing issues not only because they affect older relatives and friends, but also because people could avoid the ageing process by themselves. As health status is a major influence on an elderly person's social and economic life, it is also pertinent that government should ensure life-long healthcare services are available and affordable, particularly for the elderly.

\section{References}

Allen, T.D. (2001). Family-supportive work environments: The role of organizational perceptions. Journal of Vocational Behavior, 58. 414-435. http://dx.doi.org/10.1006/jvbe.2000.1774

Ando, A., \& Modigliani, F. (1963). The life-cycle hypothesis of saving: Aggregate implications and tests. American Economic Review, 53. 55-84.

Annamaria Lusardi (2000). Explaining why so many Households do not save. January 2000, Uni. of Chicago, U.S.

Barlett, J.F., \& Kotrlik, J.W. (1999). Development of a self-directed learning instrument for use in work environments. Journal of Vocational Education Research, 24(4). 185-208.

Bayer, P.J., Bernheim, B.D., \& Scholz, J.K. (1996). The effects of financial education in the workplace: Evidence from a survey of employers. Standard Economics, Working Paper, No. 96-011.

Becker, G.S., \& Mulligan, C.B. (1997). The endogenous determination of time preference. The Quarterly Journal of Economics, 112(3). 729-758. http://dx.doi.org/10.1162/003355397555334

Bolhuis, S. (2003). Toward process-oriented teaching for self-directed lifelong learning: A multidimensional perspective. Learning Instruction, 13(3). 327-347. http://dx.doi.org/10.1016/S0959-4752(02)00008-7

Caraher, K. (2000). Issues in incomes provision for the elderly in Malaysia in The Year 2000. International Research Conference on Social Security. International Social Security Association, Helsinki, 1-12.

Chan, A. (1997). An overview of the living arrangements and social support exchanges of older Singaporeans. Asia-Pacific Population Journal, 12(4). 1-14.

Chia, Y.C. (1996). Primary Care in the Elderly. In First Symposium on Gerontology 1995: Issues and Challenges of Ageing Multidisciplinary Perspectives: Proceedings (1995), Gerontology Association of Malaysia, Kuala Lumpur.

Clark, R.L., d'Ambrosio, M.B., McDermed, A.A., \& Sawant, K. (2003). Financial education and retirement savings. Presented at Sustainable Community Development: What Works, What Doesn't, and Why. Conference Sponsored by the Federal Reserve System, March 27-28, 2003, Washington, DC.

Department of Statistics Malaysia (2008). Population and Housing Census of Malaysia 2000. General Report of the Population Census, Kuala Lumpur.

Ekerdt, D. J., \& Hackney, J. (2002). Workers' ignorance of retirement benefits. The Gerontologist, 42. 543-551. http://dx.doi.org/10.1093/geront/42.4.543

Fletcher, C.N., Beehout, G., \& Mendenhall, S. (1997). Developing and evaluating personal finances education at the workplace: A case study. Personal Finances and Worker Productivity, 1(1). 54-59.

Fox, L., \& Palmer, E. (2001). New Approaches to Multipillar Pension Systems: What in the World is going on? In New Ideas about Old Age Security, Edited by Robert Holzmann and Joseph E. Stiglitz. Washington, DC: The World Bank. 
Friedman, M. (1957). A theory of the consumption function. Princeton, NJ: Princeton University Press.

Garman, E.T., Kim, J., Kratzer, Brunson, B.H., \& Joo, S. (1999). Workplace financial education improves personal financial wellness. Financial Counselling and Planning, 10(1). 79-88.

Hastings, J., \& Tejeda-Ashton, L. (2008). Financial literacy, information, and demand elasticity: Survey and experimental evidence from Mexico. NBER Working Paper No. 14538, Cambridge, MA.

Hershey, D.A., \& Mowen, J.C. (2000). Psychological determinants of financial preparedness for retirement. The Gerontologist, 40(6). 687-697. http://dx.doi.org/10.1093/geront/40.6.687

Hogarth, J.M., Beverly, S.G., \& Hilgert, M. (2003). Patterns of Financial Behaviors: Implications for Community Educators and Policymakers. Discussion Draft - February, 2003, 2003 Federal Reserve System Community Affairs Research Conference.

Jacobs-Lawson, J.M., \& Hershey, D.A. (2005). Influence of future time perspective, financial knowledge, and financial risk tolerance on retirement saving behaviors. Financial Services Review, 14. 331-344.

James, L.R., \& Brett, J.M. (1984). Mediators, moderators, and tests for mediation. Journal of Applied Psychology, 69. 307-321. http://dx.doi.org/10.1037/0021-9010.69.2.307

Joo, S.H., \& Garman, E.T. (1998). The potential effects of workplace financial education based on the relationship between personal financial wellness and worker job productivity. Personal Finances and Worker Productivity, 2(1). 163-173.

Joo, S.H., \& Grable, J.E. (2001). Factors associated with seeking and using professional retirement-planning help. Family and Consumer Sciences Research Journal, 30(1). 37-63. http://dx.doi.org/10.1177/1077727X01301002

Joo, S.H., \& Grable, J.E. (2005). Employee education and the likelihood of having a retirement savings program. Financial Counseling and Planning, 16(1). 37-49.

Kim, J., Kwon, J., \& Anderson, E.A. (2005). Factors related to retirement confidence: Retirement preparation and workplace financial education. Financial Counseling and Planning, 16(2). 77-89.

Kimball, M., \& Shumway, T. (2007). Investor sophistication, and the participation, home bias, diversification, and employer stock puzzles. University of Michigan, U.S.

Kumar, R.V. (1997). The role of employees' provident fund (EPF) in financing old age in Malaysia. In Proceedings of the 1996 celebrations: National day for the elderly, 17-27 October 1996, K. Lumpur.

Lim, V.K.G. (2003). An empirical study of older workers' attitudes towards the retirement experience. Employee Relations, 25(4). 330-346. http://dx.doi.org/10.1108/01425450310483361

Loibl, C., \& Hira, T.K. (2005). Self-directed financial learning and financial satisfaction. Financial Counseling and Planning, 16(1). 11-21.

Lusardi, A. (1999). Information, expectations, and savings for retirement. In Behavioral Dimensions of Retirement Economics, edited by Henry Aaron. Washington, D.C. Brookings Institution Press and Russell Sage Foundation.

Lusardi, A. (2006). Financial literacy and planning: Implications for retirement wellbeing. Pension Research Council Working Paper 1, The Wharton School.

Lusardi, A. (2007). Baby boomers retirement security: The role of planning, financial literacy and housing wealth. Journal of Monetary Economics, 54. 205-224. http://dx.doi.org/10.1016/j.jmoneco.2006.12.001

Lusardi, A. (2008). Planning and financial literacy. How do women fare? American Economic review, 98(2). 413-417. http://dx.doi.org/10.1257/aer.98.2.413

Lusardi, A., \& Mitchell, O.S. (2005). Financial Literacy and Planning: Implications for Retirement Wellbeing. Michigan Retirement Research Center, Uni. of Michigan, WP 2005-108, December 2005.

Lusardi, A., \& Tufano, P. (2008). Debt literacy, financial experiences, and overindebtedness. Working Paper, Harvard Business School and Dartmouth College, U.S.

Lyons, A.C., Chang, Y.H., \& Scherpf, E.M. (2006). Translating financial education into behavior change for low-income populations. Financial Counseling \& Planning, 17(2). 27-45.

Mannix, M. (1998). Goodbye to debt: The new American status symbol and how to achieve it. U. S. News \& World Report, April 27. 63-69. 
Mitchell, G.S., \& Moore, J.F. (1998). Can Americans afford to retire? New evidence on retirement saving adequacy. Journal of Risk and Insurance, 65. 371-400. http://dx.doi.org/10.2307/253656

Sebstad, J., \& Cohen, M. (2003). Financial education for the poor. Financial Literacy Project, Working Paper No.1, April 2003, Microfinance Opportunities, Washington D.C.

Stango, V., \& Zinman, J. (2008). Exponential growth bias and household finance. Working Paper, Dartmouth College.

Staten, M.E., Elliehausen, G., \& Lundquist, E.C. (2002). The impact of credit counseling on subsequent borrower credit usage and payment behavior. Credit Research Center Monograph \#36, Georgetown University, March 2002.

Taha, H.M., \& Mat, R. (2003). Socio-economic characteristics of the elderly in Malaysia. In 21st Population Census Conference, 19 - 21 November 2003, Kyoto, Japan.

Tan, H.K., \& Folk, J.Y. (2011). Expected retirement age: A determinant of financial planning preparation in Malaysia. African Journal of Business Management, 5(22). 9370-9384.

Tan, H.K., \& Folk, J.Y. (2011). Knowing when to Retire: The First Step Towards Financial Planning in Malaysia. Educational Gerontology, 37(10). 854-884. http://dx.doi.org/10.1080/03601277.2010.485008

Thillainathan, R. (2004). Malaysia: Pension and financial market reforms and issues on governance. In Pension in Asia: incentives, compliance and their role in retirement conference, Hitosubashi University, Tokyo, 1-40.

Van Rooij, M., Lusardi, A., \& Alessie, R. (2007). Financial literacy and stock market participation. NBER Working Paper No. 13565, MA.

Table 1. Results of scale development

\begin{tabular}{|l|c|c|c|c|}
\hline Scale Name & $\begin{array}{c}\text { Cronbach } \\
\text { Alpha }(\alpha)\end{array}$ & KMO & Signi. & $\begin{array}{r}\text { Resultant Subscale/[Questionnaire Item] } \\
\hline \begin{array}{l}\text { Financial } \\
\text { Literacy }\end{array}\end{array}$ \\
\hline $\begin{array}{l}\text { Economic } \\
\text { well-Being }\end{array}$ & 0.894 & 0.876 & .000 & $\begin{array}{c}\text { LITEXPL - [Q.D3(a) to D3(e)] } \\
\text { LITKNOW - [Q.D5(a) to D5(e)] }\end{array}$ \\
& 0.834 & .000 & $\begin{array}{r}\text { FINSAT - [Q.B1(b)(c)]; SUBPERC - [Q.B8,B9] } \\
\text { PERWELL - [Q.B1(a)(d)(e)(f),B5] }\end{array}$ \\
\hline
\end{tabular}


Table 2. Demographic profile

\begin{tabular}{|l|c|c|c|c|}
\hline & Minimum & Maximum & Mean & Std. deviation \\
\hline Ethnic & 1 & 4 & 2.02 & 0.489 \\
\hline Gender & 1 & 2 & 1.54 & 0.499 \\
\hline Education & 1 & 4 & 3.66 & 0.625 \\
\hline Employment Type & 1 & 4 & 2.79 & 0.812 \\
\hline Marital Status & 1 & 4 & 1.55 & 0.617 \\
\hline No. of Children & 0 & 6 & 1.01 & 1.343 \\
\hline Home ownership & 0 & 2 & 1.36 & 0.486 \\
\hline Age & 1 & 7 & 2.25 & 1.366 \\
\hline Income & 0 & 10 & 3.81 & 2.664 \\
\hline
\end{tabular}

\begin{tabular}{|c|c|c|c|c|c|c|c|c|c|c|c|c|c|}
\hline Description & \multicolumn{2}{|c|}{ Gender } & \multicolumn{4}{|c|}{ Educational Status } & \multicolumn{3}{|c|}{ Ethnicity } & \multicolumn{4}{|c|}{ Employment Type } \\
\hline & $\mathrm{M}$ & $\mathrm{F}$ & None & Prim & Second & Tertiary & $\mathrm{M}$ & $\mathrm{C}$ & I & Self & Public & Private & Other \\
\hline Frequency & 199 & 205 & 6 & 14 & 87 & 297 & 39 & 333 & 32 & 46 & 60 & 240 & 58 \\
\hline$\%$ & 49.3 & 50.7 & 1.5 & 3.5 & 21.5 & 73.5 & 9.6 & 82.5 & 7.9 & 11.3 & 14.9 & 59.4 & 14.4 \\
\hline Description & \multicolumn{2}{|c|}{ Own Home } & \multicolumn{3}{|c|}{ Marital Status } & \multicolumn{3}{|c|}{ Children } & \multicolumn{5}{|c|}{ Age Group } \\
\hline & Yes & No & Single & Married & Other & 0 & 1 & $\geq 2$ & $\begin{array}{c}20- \\
29\end{array}$ & $\begin{array}{c}30- \\
39\end{array}$ & $\begin{array}{c}40- \\
49\end{array}$ & $\begin{array}{c}50- \\
59\end{array}$ & $\begin{array}{l}\geq \\
60\end{array}$ \\
\hline Frequency & 260 & 144 & 209 & 179 & 16 & 235 & 39 & 130 & 149 & 127 & 60 & 36 & 32 \\
\hline$\%$ & 64.4 & 35.6 & 51.7 & 44.4 & 3.9 & 58.2 & 9.7 & 32.1 & 36.9 & 31.4 & 14.9 & 8.9 & 7.9 \\
\hline
\end{tabular}

Table 3. Hypothesis results

\begin{tabular}{|c|c|c|c|c|}
\hline Hypothesis & Type & $\Delta \mathrm{R}^{2}$ & Signi. & Significant Variables \\
\hline $\begin{array}{l}\text { H1.1: Controlling for demographic attributes, financial } \\
\text { learning makes a significant contribution to financial } \\
\text { literacy explanation. }\end{array}$ & Hier. & .139 & $.000 * *$ & Q.D1eA,D2bA,Attend,F1 \\
\hline $\begin{array}{l}\text { H1.2: Controlling for demographic attributes, financial } \\
\text { learning makes a significant contribution to financial } \\
\text { literacy knowledge. }\end{array}$ & Hier. & .151 & $.000 * *$ & $\begin{array}{l}\text { D1eA, D2cA, D2eA, } \\
\text { D2fA, Skill, Attend, } \\
\text { Ethnic, DEduc, F1 }\end{array}$ \\
\hline $\begin{array}{l}\text { H2.1: Controlling for demographic attributes and } \\
\text { financial learning, financial literacy makes a } \\
\text { significant contribution to Subjective Perception of } \\
\text { Personal Finance (SUBPERC). }\end{array}$ & Hier. & .021 & $.011 *$ & $\begin{array}{l}\text { D2eA, D1dA, D1eA, } \\
\text { Home,DAge5, F1 }\end{array}$ \\
\hline $\begin{array}{l}\text { H2.2: Controlling for demographic attributes and } \\
\text { financial learning, financial literacy makes a } \\
\text { significant contribution to Behavioural Assessment of } \\
\text { Personal Finance (BEHASS). }\end{array}$ & Hier. & .032 & $.002 * *$ & $\begin{array}{l}\text { LITKNOW, D2aA, } \\
\text { DEduc, F1 }\end{array}$ \\
\hline $\begin{array}{l}\text { H2.3: Controlling for demographic attributes and } \\
\text { financial learning, financial literacy (LITERACY) } \\
\text { makes a significant contribution to Satisfaction with } \\
\text { Financial Situation (FINSAT). }\end{array}$ & Hier. & .042 & $.000 * *$ & $\begin{array}{l}\text { LITKNOW, D1eA, D2eA, } \\
\text { Ethnic,DAge5 }\end{array}$ \\
\hline $\begin{array}{l}\text { H2.4: Controlling for demographic attributes and } \\
\text { financial learning, financial literacy makes a } \\
\text { significant contribution to perceived financial } \\
\text { well-being (PERWELL). }\end{array}$ & Hier. & .018 & $.017 *$ & $\begin{array}{c}\text { LITKNOW, D2eA, } \\
\text { D1eA,DEduc, Gender, F1, } \\
\text { DEduc, DMarr1, DAge3, } \\
\text { DAge4, DAge5 }\end{array}$ \\
\hline $\begin{array}{l}\text { H3.1: Financial literacy mediates the relationship } \\
\text { between financial learning and behavioural assessment } \\
\text { of personal finance (BEHASS). }\end{array}$ & Hier. & .032 & $.002 * *$ & $\begin{array}{c}\text { DEduc, D2aA, D2eA, } \\
\text { LITKNOW }\end{array}$ \\
\hline $\begin{array}{l}\text { H3.2: Financial literacy mediates the relationship } \\
\text { between financial learning and perceived financial } \\
\text { well-being (PERWELL). }\end{array}$ & Hier. & .018 & $.017^{*}$ & $\begin{array}{l}\text { DEduc, Gender, DMarr1, } \\
\text { F1, DAge2, DAge3, } \\
\text { DAge4, DAge5, D1eA, } \\
\text { LITKNOW }\end{array}$ \\
\hline $\begin{array}{l}\text { H3.3: Financial literacy mediates the relationship } \\
\text { between financial learning and satisfaction with } \\
\text { financial situation (FINSAT). }\end{array}$ & Hier. & .042 & $.000 * *$ & $\begin{array}{c}\text { Ethnic, F1, DAge5, D2eA, } \\
\text { D1eA, LITKNOW }\end{array}$ \\
\hline $\begin{array}{l}\text { H3.4: Financial literacy mediates the relationship } \\
\text { between financial learning and subjective perception } \\
\text { of personal finance (SUBPERC). }\end{array}$ & Hier. & .021 & $.011^{*}$ & $\begin{array}{l}\text { Home, F1, DAge5, D2eA, } \\
\text { D1dA, D1eA, LITEXPL }\end{array}$ \\
\hline
\end{tabular}

Note: $* \rho<0.05 ; * * \rho<0.01$ 


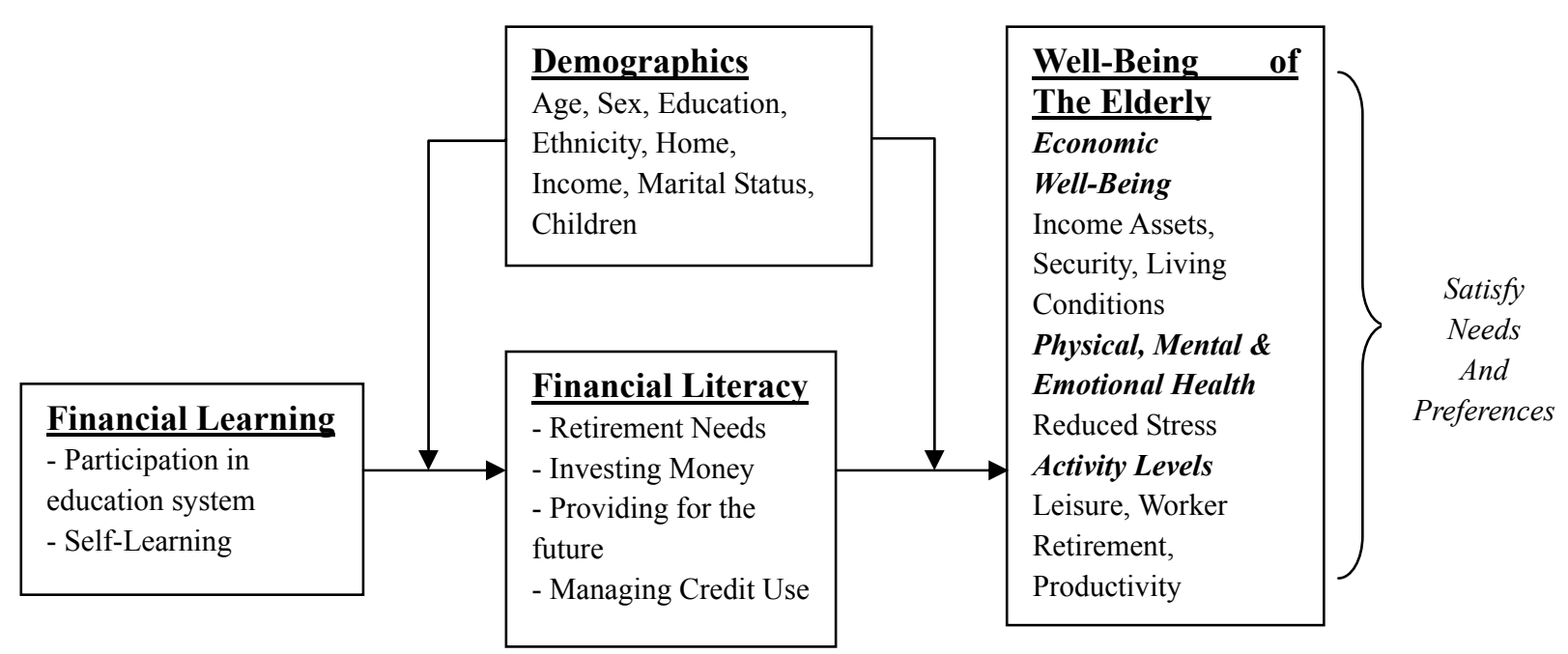

Figure 1. Conceptual framework of factors affecting well-being of the elderly 